\title{
An Analysis of Problems and Constraints Faced by Farmers in Marketing of Agricultural Produce in Punjab
}

\author{
Namami Gohain* and Sukhpal Singh \\ Department of Economics and Sociology, PAU, Ludhiana, Punjab-141004, India \\ *Corresponding author: jeniffertime@gmail.com
}

\begin{abstract}
Agriculture as an economic activity is subjected to serious risk of natural conditions and price risk. Some of the important constraints of agricultural marketing system in the country are lack of infrastructure like storage, transportation, quality control, packaging, price risk management, cool chains, market led extension, and condusive framework for promotion of contract farming. The present study was undertaken in the state of Punjab to study the problems of farmers in the marketing of paddy, wheat, maize and cotton. A total sample of 180 farmers from 12 villages of six districts was selected for the study. The sample farmers were further categorized, based on their operational holding, as marginal, small, semi-medium, medium and large farmers. The results from the study indicated that the most important problem identified by the farmers in the marketing of paddy and wheat was the delay in procurement of paddy in the markets followed by the deduction of payments by commission agents due to higher moisture content in the grains. However, the major problem during marketing of basmati was the exploitative practices by the intermediaries followed by lack of public procurement. The problem faced by majority of farmers in the marketing of maize and cotton was the lack of public procurement of the produce and lack of remunerative price of the crop respectively.
\end{abstract}

Keywords: Marketing, constraints, procurement, Garretts' ranking, agricultural produce

Agriculture as an economic activity is subjected to serious risk of natural conditions and price risk. At international, national and APMC levels there exists a number of problems related to agriculture marketing. Before independence, Indian agriculture was mostly in the nature of subsistence farming where the farmers sold only a small part of their produce to pay off rents, debts and meet their other requirements at prices considerably lower than the market prices. The farmers who took their produce to mandis i.e. whole sale market also faced number of problems. There was a large chain of intermediaries in the agriculture marketing system like village traders, kutcha arhityas, pucca arhatiyas, brokers, wholesalers, retailers, and moneylenders. Lack of infrastructure like storage, transportation, quality control, packaging, price risk management, cool chains, market led extension, and conducive framework for promotion of contract farming are some of the other important constraints for competitive agricultural marketing system in the country. Lack of owned storage and substandard transportation facilities came in the way of decision making by the farmers on the storage front. Hence, about 90 per cent of the marketable surplus was disposed off just after the harvest (Rajesh and Sundaresan, 2002). Moreover, due to lack of food processing and storage, the grower farmer is deprived of a good price for his produce during the peak marketing season while the consumer needlessly pays a higher price during lean season (Ramkishen, 2004).

Punjab State Agricultural Marketing Board was established on $26^{\text {th }}$ May, 1961 under the Punjab Agricultural Produce Markets Act, 1961 with an objective to control and supervise the marketing network of sale, purchase, storage and processing of processed or nor processed agriculture animal 
husbandry and forest produce. Punjab has a vast network of 151 principal markets, 284 sub-yards and over 1395 purchase centres scattered throughout the rural areas in 2017-18. The regulation of agricultural markets in the state has been able to fathom some common problems hindering the efficient performance of the marketing function.

In Punjab, about 78 per cent non-member farmers had either inadequate or no access to pre-cooling and cold storage facilities created in their area. However, majority of the member farmers did not face any constraints. Other major constraints faced by the farmers of Punjab included shortage of skilled labour, lack of market information, higher wages and lack of mechanized centres. Among the constraints related to packing, the shortage of material, its high price and non-availability of credit were delineated as the major constraints in case of horticultural produce. High transportation cost was a serious constraint followed by nonavailability of vehicles for transport of horticultural produce. About one among every four farmers complained that the charges deducted by the market functionaries were high (Kshirsagar, 2006).

As mentioned in Planning Commission Report, the facilities created in market yards continue to be inadequate. The report further stated that the market committees have not popularized the cleaning, grading and packaging of agricultural produce on a sufficient scale before sale by the farmers. Even facilities for these have not been created in most of the market yards. Report further states that the benefits available to the farmers from regulated markets depend on the facilities/amenities available rather than the number of regulated markets in the area. Both covered and open auction platforms exist in $66 \%$ of the regulated markets. Only $25 \%$ of the markets have common drying yards. The cold storage units exist in only $9 \%$ of the markets and grading facilities exist in less than $33 \%$ of the markets. The basic facilities viz., internal roads, boundary walls, electric light, loading and unloading facilities and weighing equipment's are available in more than $80 \%$ of the markets. Farmer's rest houses exist in $50 \%$ of the regulated markets. In this backdrop, the present study was undertaken with the objective of analyzing the various constraints faced by the farmers of Punjab during marketing of farm produce. Study of problems faced by the framers would be helpful in determining the aspects of the infrastructural facilities which need further improvement.

\section{Database and Methodology}

The present study was undertaken in the state of Punjab to study the problems of farmers in the marketing of paddy, wheat, maize and cotton. A total of six districts were selected for the study namely Ludhiana, Patiala and Amritsar from central zone; Hoshiarpur from sub-mountainous zone and Faridkot and Mansa from south western zone. Furthermore, two villages from each district were selected, from which a sample of 180 farmers of were selected for the study. The primary data for the study pertains to the period 2016-17.

The sample farmers for the purpose of study were categorized, based on their operational holding, as marginal ( $<1$ ha of operational holding), small (1-2 ha), semi-medium (2-4 ha), medium (4-10 ha) and large farmers ( $<10 \mathrm{ha})$ according to the area under cultivation of various crops. Table- 1 shows the category wise number of farmers under each crop. It could be seen from the table that out of 158 farmers under paddy and wheat, about 16 per cent farmers were marginal, 20 per cent small, 28 per cent semi-medium, 25 per cent medium and

Table 1: Category wise distribution of sample farmers of major crops

\begin{tabular}{ccccccc}
\hline \multirow{2}{*}{ Crops } & \multicolumn{7}{c}{ Categories of farmers } \\
\cline { 2 - 7 } & Marginal & Small & Semi-medium & Medium & Large & Total \\
\hline Paddy \& wheat & $26(16.46)$ & $31(19.62)$ & $45(28.48)$ & $39(24.68)$ & $17(10.76)$ & $158(100)$ \\
Basmati & $2(4.44)$ & $5(11.11)$ & $7(15.56)$ & $12(26.67)$ & $19(42.22)$ & $45(100)$ \\
Maize & $5(9.26)$ & $10(18.52)$ & $19(35.19)$ & $13(24.07)$ & $7(12.96)$ & $54(100)$ \\
Cotton & $7(11.67)$ & $12(20.00)$ & $11(18.33)$ & $17(28.33)$ & $13(21.67)$ & $60(100)$ \\
Fruits & $4(7.02)$ & $9(15.79)$ & $13(22.81)$ & $19(33.33)$ & $12(21.05)$ & $57(100)$ \\
Vegetables & $14(22.95)$ & $19(31.15)$ & $11(18.03)$ & $12(19.67)$ & $5(8.20)$ & $61(100)$ \\
\hline
\end{tabular}


10 per cent large farmers. However, for basmati, the corresponding values were 4 per cent, 11 per cent, 16 per cent, 27 per cent and 42 per cent. Out of 54 maize farmers, about 9 per cent farmers were marginal, 19 per cent small, 35 per cent semimedium, 24 per cent medium and 12 per cent large farmers. For cotton, the sample farmers consisted of 12 per cent marginal, 20 per cent small, 18 per cent semi-medium, 28 per cent medium and 22 per cent large farmers. The corresponding values for fruits were 7 per cent, 16 per cent, 23 per cent, 33 per cent and 21 per cent. It was seen that out of 61 vegetable farmers, about 23 per cent were marginal, 31 per cent small, 18 per cent semi-medium, 20 per cent medium and 8 per cent large farmers.

Garrett's ranking technique is employed for ranking the preferences of respondents on different variables. This method helps to identify the most significant variable influencing the respondent. By this method the respondents are asked to rank their preference for all factors. The resultant outcomes of such rankings are converted to per cent position using the formula:

$$
\text { Percent position }=\frac{100\left(R_{i j}-0.5\right)}{N_{j}}
$$

Where,

$R_{i j}=$ Rank given for the $\mathrm{i}^{\text {th }}$ variable by $\mathrm{j}^{\text {th }}$ respondents.

$N_{j}=$ Number of variable ranked by $\mathrm{j}^{\text {th }}$ respondents.

From the Garrett's Table, the percent position calculated is converted into scores. Then for each factor, the scores of each individual are added and then total value of scores and mean values of score is calculated. The factors having highest mean value is considered to be the most important factor.

\section{RESULTS AND DISCUSSION}

It is to be noted that the constraints of marketing of farm produce by the farmers are presented crop wise and farmer category wise. The crops selected for the purpose of study were paddy (including basmati), wheat, maize and cotton. Various suggestions given by the farmers to address the problems faced by farmers are also enlisted in this section. Details of crop wise and category wise problems of the farmers in marketing of their produce and the suggestions to address these problems are presented below.

Punjab is rightly called the "granary of India". It produces about 2.4 per cent of world's wheat, about 2.3 per cent of world's paddy and about 1 per cent of the world's cotton. Almost 82 per cent of the area in the state was under cultivation out of which almost 85 per cent of the cropped area was under wheat and 73 per cent under paddy. Table 2 shows the category wise problems faced by wheat and paddy farmers in Punjab during marketing of their produce. It was seen that majority of the marginal farmers, about 88 per cent had the problem of delayed procurement particularly in case of paddy and about 92 per cent of the marginal farmers faced the problem of delayed payment in case of both paddy and wheat, while marketing their produce. About 93 per cent of the small farmers faced the problem of delayed payment and exploitation by market intermediaries and about 87 per cent of them faced the problem of delayed procurement of paddy. It was also seen that about 93 per cent

Table 2: Category wise problems faced during marketing of wheat and paddy in Punjab (Multiple response)

\begin{tabular}{cccccc}
\hline \multirow{2}{*}{ Problems / Constraints } & \multicolumn{5}{c}{ Categories of farmers (Frequency) } \\
\cline { 2 - 6 } & Marginal & Small & Semi-medium & Medium & Large \\
\hline Delay in procurement (Paddy) & $23(88.46)$ & $27(87.10)$ & $42(93.33)$ & $35(89.74)$ & $12(70.59)$ \\
Deduction in payments by commission agents & $19(73.08)$ & $20(64.52)$ & $38(84.44)$ & $27(69.23)$ & $6(35.29)$ \\
Lack of remunerative price of crop & $10(38.46)$ & $14(45.16)$ & $30(66.67)$ & $23(58.97)$ & $7(41.18)$ \\
Lack of shed availability & $20(65.38)$ & $22(70.97)$ & $25(55.56)$ & $29(74.36)$ & $8(47.06)$ \\
Exploitative practices of intermediaries & $17(76.92)$ & $29(93.55)$ & $36(80.00)$ & $24(61.54)$ & $14(82.35)$ \\
Lack of dryers in the market & $16(61.54)$ & $18(58.06)$ & $40(88.89)$ & $30(76.92)$ & $15(88.24)$ \\
Delay in payment & $24(92.31)$ & $29(93.55)$ & $36(80.00)$ & $28(71.79)$ & $9(52.94)$ \\
Total number of farmers & $26(100)$ & $31(100)$ & $45(100)$ & $39(100)$ & $17(100)$ \\
\hline
\end{tabular}

Figures in parenthesis indicate percentage to total. 
and 90 per cent of the semi-medium and medium farmers, respectively faced the problem of delayed procurement while marketing of paddy and wheat in the markets of Punjab. However majority of large farmers $(88 \%)$ faced the problem of lack of dryers in the markets.

Using Garrett's ranking technique, the various problems faced by the wheat and paddy growers of Punjab were studied and the results are presented in descending order of their relative importance in table 3. All the sample farmers identified eight major problems encountered during the marketing of wheat and paddy. The most important problem identified by the farmers in the study area was the delay in procurement of paddy in the markets. The second major problem identified by the farmers was the deduction by commission agents due to higher moisture content in the grains. The next problem rated by the wheat and paddy growers of the state was the lack of remunerative price of crop. Their efforts were paid off very little as they didn't receive the remunerative price for their produce in the market. Lack of shed availability was ranked the fourth major problem due to which the farmers were compelled to keep their produce in the open exposing them to the vagaries of nature. This was followed by the problem of exploitative practices of the intermediaries such as faulty weighing practices. Lack of dryers in the markets was ranked the sixth followed by delay in payment which was ranked as seventh.
Table 3: Ranking of problems and constraints faced by farmers in the marketing of wheat and paddy in Punjab

\begin{tabular}{ccc}
\hline Problems / Constraints & $\begin{array}{c}\text { Garrett's } \\
\text { mean score }\end{array}$ & Rank \\
\hline Delay in procurement (paddy) & 72.76 & $\mathrm{I}$ \\
Deduction in payments by & 63.98 & $\mathrm{II}$ \\
$\begin{array}{c}\text { commission agents } \\
\text { Lack of remunerative price of crop }\end{array}$ & 59.01 & $\mathrm{III}$ \\
Lack of shed availability & 54.65 & $\mathrm{IV}$ \\
$\begin{array}{c}\text { Exploitative practices of } \\
\text { intermediaries }\end{array}$ & 52.68 & $\mathrm{~V}$ \\
$\begin{array}{c}\text { Lack of dryers in the market } \\
\text { Delay in payment }\end{array}$ & 38.45 & $\mathrm{VI}$ \\
\hline
\end{tabular}

It was seen that almost all the categories of farmers faced the problem of lack of MSP in case of basmati (table 4). Moreover, all the marginal and small farmers faced the problems of exploitative practices of intermediaries, lack of public procurement, and lack of shed availability. The problems of lack of public procurement and lack of dryers in the markets were faced by almost 86 per cent of the semi-medium farmers. About 92 per cent of the medium farmers faced the problem of lack of dryers in the markets whereas 95 per cent of the large farmers' opined lack of public procurement as the major problem faced during the marketing of basmati.

With the help of Garrett ranking technique, various problems faced by the basmati growers of Punjab were ranked in descending order of their importance

Table 4: Category wise problems faced during marketing of basmati in Punjab (Multiple response)

\begin{tabular}{cccccc}
\hline \multirow{2}{*}{ Problems / Constraints } & \multicolumn{5}{c}{ Categories of farmers (Frequency) } \\
\cline { 2 - 6 } & Marginal & Small & Semi-medium & Medium & Large \\
\hline Exploitative practices of intermediaries & $2(100.00)$ & $5(100.00)$ & $5(71.43)$ & $10(83.33)$ & $15(78.95)$ \\
Lack of public procurement & $2(100.00)$ & $5(100.00)$ & $6(85.71)$ & $9(75.00)$ & $18(94.74)$ \\
Lack of MSP & $2(100.00)$ & $5(100.00)$ & $7(100.00)$ & $12(100.00)$ & $19(100.00)$ \\
Delay in procurement & $1(50.00)$ & $2(40.00)$ & $4(57.14)$ & $7(58.33)$ & $10(52.63)$ \\
Deduction in payments by commission agents & $1(50.00)$ & $3(60.00)$ & $3(42.86)$ & $4(33.33)$ & $7(36.84)$ \\
Lack of dryers in the market & $1(50.00)$ & $4(80.00)$ & $6(85.71)$ & $11(91.67)$ & $11(57.89)$ \\
Lack of shed availability & $2(100.00)$ & $2(40.00)$ & $4(57.14)$ & $6(41.67)$ & $6(31.58)$ \\
Total number of farmers & $2(100)$ & $5(100)$ & $7(100)$ & $12(100)$ & $19(100)$ \\
\hline
\end{tabular}

Figures in parenthesis indicate percentage to total. 
as shown in the table 5. During the marketing of basmati, the major problem faced by the farmers was the exploitative practices by the intermediaries followed by lack of public procurement which was ranked second. Lack of MSP was ranked the third most important problem faced by the famers in the marketing of basmati in the study area. Next to it was the delay in procurement of the produce by various procurement agencies followed by the problem of deduction in payments by commission agents which were ranked fourth and fifth respectively. Next problem identified was the lack of dryers in the market followed by the problem of unavailability of shed in the markets which were ranked sixth and seventh respectively.

Table 5: Ranking of problems and constraints faced by farmers in the marketing of Basmati in Punjab

\begin{tabular}{ccc}
\hline Constraints/ problems & $\begin{array}{c}\text { Garrett's } \\
\text { mean score }\end{array}$ & Rank \\
\hline $\begin{array}{c}\text { Exploitative practices of } \\
\text { intermediaries }\end{array}$ & 73.16 & $\mathrm{I}$ \\
Lack of public procurement & 65.45 & $\mathrm{II}$ \\
Lack of MSP & 56.07 & $\mathrm{III}$ \\
Delay in procurement & 53.75 & $\mathrm{IV}$ \\
Deduction by commission agents & 45.24 & $\mathrm{~V}$ \\
Lack of dryers in the market & 33.64 & $\mathrm{VI}$ \\
Lack of shed availability & 26.91 & VII \\
\hline
\end{tabular}

Before the advent of paddy, the main kharif crops in the state were maize, cotton and pulses. In 1960, about 3 lakh hectares of cultivable area was under paddy which increased to about 30 lakh hectares in the recent years. In 1970-71, the gross cropped area under maize was 9.7 per cent which came down to 1.7 per cent in 2010-11. The problem of lack of public procurement of maize was faced by majority of farmers in all the categories, 100 per cent, 90 per cent, 84 per cent, 85 per cent and 86 per cent of the marginal, small, semi-medium, medium and large farmers, respectively (table 6). The problem of lack of maize dryers were faced by about 80 per cent, 100 per cent, 89 per cent, 100 per cent and 71 per cent of the marginal, small, semi-medium, medium and large farmers, respectively. About 80 per cent of marginal farmers, 80 per cent small, 63 per cent semi-medium, 80 per cent medium and 100 per cent large farmers' opined lack of remunerative price for their produce as a problem faced during marketing of maize.

The major problem faced by the farmers in the marketing of maize was the lack of public procurement of the produce due to which farmers were left at the mercy of the private traders who procure their produce at prices lower than the recommended MSP (table 7). The results were supported by the findings of Chahal and Kataria, 2010. The next major problem was the exploitative practices by middlemen followed by lack of dryers ranked as second and third, respectively. Due to lack of dryers in the market the farmers had to wait for long for their produce to be procured. The fourth problem identified by the farmers of the study area was the lack of remunerative price for the crop followed by delayed procurement of the produce which was ranked fifth. Fluctuation in the price of the produce followed by distress sale was ranked as the sixth and seventh problem in the marketing of maize. The findings of the study were supported by the results of Kumari, Meena and Singh, 2015.

Table 6: Category wise problems faced during marketing of maize in Punjab (Multiple response)

\begin{tabular}{|c|c|c|c|c|c|}
\hline \multirow{2}{*}{ Problems / Constraints } & \multicolumn{5}{|c|}{ Categories of farmers (Frequency) } \\
\hline & Marginal & Small & Semi-medium & Medium & Large \\
\hline Lack of public procurement & $5(100.00)$ & $9(90.00)$ & $16(84.21)$ & $11(84.62)$ & $6(85.71)$ \\
\hline Lack of dryers in the market & $4(80.00)$ & $10(100.00)$ & $17(89.47)$ & $13(100.00)$ & $5(71.43)$ \\
\hline Lack of remunerative price of the crop & $4(80.00)$ & $8(80.00)$ & $12(63.16)$ & $10(76.92)$ & $7(100.00)$ \\
\hline Price fluctuation & $3(60.00)$ & $7(70.00)$ & $10(52.63)$ & $9(69.23)$ & $5(71.43)$ \\
\hline Distress sale & $2(40.00)$ & $4(40.00)$ & $5(26.32)$ & $3(23.08)$ & $2(28.57)$ \\
\hline Total number of farmers & $5(100)$ & $10(100)$ & $19(100)$ & $13(100)$ & $7(100)$ \\
\hline
\end{tabular}

Figures in parenthesis indicate percentage to total. 
Table 7: Ranking of problems and constraints faced by farmers in the marketing of maize in Punjab

\begin{tabular}{ccc}
\hline Problems / Constraints & $\begin{array}{c}\text { Garrett's } \\
\text { mean score }\end{array}$ & Rank \\
\hline Lack of public procurement & 72.89 & $\mathrm{I}$ \\
Exploitative practices of middlemen & 58.72 & $\mathrm{II}$ \\
Lack of dryers in the market & 57.89 & $\mathrm{III}$ \\
Lack of remunerative price of the crop & 52.72 & IV \\
Delayed procurement & 39.89 & $\mathrm{~V}$ \\
Price fluctuation & 37.17 & $\mathrm{VI}$ \\
Distress sale & 21.73 & $\mathrm{VII}$ \\
\hline
\end{tabular}

Cotton often termed by farmers as 'white gold' for bringing higher remuneration is an important cash crop of Punjab grown extensively in the districts Bathinda, Mansa, Faridkot, Ferozpur, Muktsar, Moga, Barnala and Sangrur. In the recent years cotton is grown in about 9 per cent of the cropped area of Punjab with a production of 11.43 lakh bales and an average yield of $756 \mathrm{~kg}$ per hectare in 2016-17. Data on category wise problems of farmers during marketing of cotton in Punjab is shown in table- 8 . It could be seen that almost all the small, semi-medium and large farmers faced the problem of price fluctuation in marketing of cotton. The problem of lack of remunerative price of cotton was faced by 71 per cent of marginal, 83 per cent of small, 100 per cent of semi-medium, 82 per cent of medium and 92 per cent of large farmers. Lack of market information was another major problem opined by the cotton farmers during marketing of their produce.

Analysis of various problems faced by cotton growers in the study area revealed six different problems which were ranked accordingly using Garrett's ranking technique as shown in table- 9. The major problem identified by the cotton growers was the lack of remunerative price of the crop. Cotton being a cash crop is highly capital intensive but the price received by the farmers in return of their efforts is very less. The next important problem faced by the farmers during the marketing of cotton was the fluctuation in the price of the crop. The results obtained from analysis were consistent with the findings of Ramesh, 2014. However delayed procurement was ranked third followed by distress sale which was ranked fourth. Exploitative practices by middlemen and lack of market information were ranked fifth and sixth, respectively.

In order to deal with the problems faced by the farmers in the marketing of wheat and paddy in the state of Punjab, various suggestions were

Table 8: Category wise problems faced during marketing of cotton in Punjab (Multiple response)

\begin{tabular}{|c|c|c|c|c|c|}
\hline \multirow{2}{*}{ Problems / Constraints } & \multicolumn{5}{|c|}{ Categories of farmers (Frequency) } \\
\hline & Marginal & Small & Semi-medium & Medium & Large \\
\hline Lack of remunerative price of the crop & $5(71.43)$ & $10(83.33)$ & $11(100.00)$ & $14(82.35)$ & $12(92.31)$ \\
\hline Price fluctuation & $6(85.71)$ & $12(100.00)$ & $11(100.00)$ & $15(88.24)$ & $13(100.00)$ \\
\hline Delayed procurement & $3(42.86)$ & $5(41.67)$ & $5(45.45)$ & $7(41.18)$ & $7(53.85)$ \\
\hline Distress sale & $2(28.57)$ & $3(25.00)$ & $3(27.27)$ & $3(17.65)$ & $2(15.38)$ \\
\hline Exploitative practices of middlemen & $2(28.57)$ & $7(58.33)$ & $4(36.67)$ & $9(52.94)$ & $8(61.54)$ \\
\hline Lack of market information & $4(57.14)$ & $8(66.67)$ & $8(72.73)$ & $12(70.59)$ & $11(84.62)$ \\
\hline Total number of farmers & $7(100)$ & $12(100)$ & $11(100)$ & $17(100)$ & $13(100)$ \\
\hline
\end{tabular}

Figures in parenthesis indicate percentage to total.

Table 9: Ranking of problems and constraints faced by farmers in the marketing of cotton in Punjab

\begin{tabular}{ccc}
\hline Problems / Constraints & Garrett's mean score & Rank \\
\hline Lack of remunerative price of the crop & 73.10 & I \\
Price fluctuation & 68.80 & II \\
Delayed procurement & 56.33 & III \\
Distress sale & 50.07 & IV \\
Exploitative practices of middlemen & 42.90 & V \\
Lack of market information & 32.87 & VI \\
\hline
\end{tabular}


made by the sample farmers as shown in table10. It could be seen from the table that majority of the farmers (89\%) suggested encouragement of spot payment for their produce, 76 per cent of the farmers suggested that there should not be any delay in the procurement of produce, 56 per cent of farmers suggested measures to check exploitation by intermediaries and 54 per cent farmers suggested construction of covered sheds in the markets.

Table 10: Suggestions by farmers to address problems of marketing of wheat and paddy (Multiple response $(\mathrm{N}=158))$

\begin{tabular}{ccc}
\hline Suggestions & Frequency & Percentage \\
\hline $\begin{array}{c}\text { Timely procurement of farm } \\
\text { produce }\end{array}$ & 120 & 75.95 \\
$\begin{array}{c}\text { Stop deduction by commission } \\
\text { agents }\end{array}$ & 53 & 33.54 \\
$\begin{array}{c}\text { Construction of covered sheds } \\
\text { in the markets }\end{array}$ & 85 & 53.80 \\
$\quad \begin{array}{l}\text { Installing of dryers } \\
\text { Check exploitation of market } \\
\quad \text { intermediaries }\end{array}$ & 50 & 31.65 \\
$\quad$ Encourage spot payment & 140 & 55.70 \\
\hline
\end{tabular}

About 87 per cent of the sample farmers suggested checking the exploitative practices of market intermediaries while 84 per cent of the farmers suggested public procurement of basmati which would give them a remunerative price for their crop (table 11). It was also seen that about 66 per cent of the farmers suggested introduction of MSP for basmati and about 60 per cent of the farmers suggested installation of dryers in the grain markets.

Table 11: Suggestions given by farmers to address problems of marketing of basmati in Punjab (Multiple response $(\mathrm{N}=45))$

\begin{tabular}{ccc}
\hline Suggestions & Frequency & Percentage \\
\hline $\begin{array}{c}\text { Checking the exploitative } \\
\text { practices of market intermediaries } \\
\text { There should be public } \\
\text { procurement }\end{array}$ & 39 & 86.67 \\
$\begin{array}{c}\text { Introduction of MSP for basmati } \\
\text { Timely procurement of the } \\
\text { produce in the market }\end{array}$ & 30 & 84.44 \\
$\begin{array}{c}\text { Installation of dryers in the } \\
\text { markets }\end{array}$ & 27 & 66.67 \\
$\begin{array}{c}\text { Construction of covered sheds in } \\
\text { the markets }\end{array}$ & 25 & 50.00 \\
\hline
\end{tabular}

To address the problems faced by the farmers during the marketing of maize in the state of Punjab the suggestions made by the sample farmers are presented in table 12. It was seen that about 89 per cent of the farmers suggested effective public procurement of maize which would help them to get a remunerative price for their produce and would also prevent exploitation by private traders. Almost 67 per cent of the farmers suggested installation of maize dryers in the markets as there is a moisture problem in the maize produce which becomes a hindrance in the procurement of the crop. About 61 per cent of the sample farmers suggested a remunerative MSP for the maize crop while 41 per cent of the farmers suggested spot payment for farm produce.

Table 12: Suggestions given by farmers to address problems of marketing of maize in Punjab (Multiple response $(\mathrm{N}=54))$

\begin{tabular}{ccc}
\hline Suggestions & Frequency & Percentage \\
\hline Effective public procurement & 48 & 88.89 \\
$\begin{array}{c}\text { Measures to be taken to reduce } \\
\text { the exploitative practices of } \\
\quad \text { intermediaries }\end{array}$ & 20 & 37.03 \\
$\begin{array}{c}\text { Installation of maize dryers in the } \\
\text { markets }\end{array}$ & 36 & 66.67 \\
$\quad \begin{array}{c}\text { Remunerative MSP } \\
\text { Timely procurement of produce } \\
\text { from the market }\end{array}$ & 33 & 61.11 \\
Spot payment for farm produce & 22 & 35.19 \\
\hline
\end{tabular}

Table 13: Suggestions given by farmers to address problems of marketing of cotton in Punjab (Multiple response $(\mathrm{N}=60))$

\begin{tabular}{ccc}
\hline Suggestions & Frequency & Percentage \\
\hline Remunerative MSP & 44 & 73.33 \\
$\begin{array}{c}\text { Checking fluctuation in cotton } \\
\text { prices }\end{array}$ & 49 & 81.67 \\
$\begin{array}{c}\text { Timely procurement of farm } \\
\text { produce }\end{array}$ & 21 & 35.00 \\
$\begin{array}{c}\text { Checking the exploitative practices } \\
\text { of middlemen }\end{array}$ & 24 & 40.00 \\
Appropriate market information & 28 & 46.67 \\
\hline
\end{tabular}

In order to deal with the problems faced by the farmers in the marketing of cotton in Punjab, various suggestions were made by the sample farmers as shown on table 13. Majority of the farmers $(82 \%)$ suggested a check in the fluctuation of prices of cotton. It was seen that almost 73 per 
cent of the farmers suggested a remunerative MSP for their produce.

\section{CONCLUSION}

Garrett's ranking technique to identify problems and constraints of farmers in marketing of their produce revealed that in case of wheat and paddy the most important problem identified by the farmers in the study area was the delay in procurement of the paddy in the markets followed by deduction in payments by commission agents due to higher moisture content in the grains. For basmati the major problem faced by the farmers was the exploitative practices of the intermediaries followed by lack of public procurement which was ranked second. In case of maize, the major problem faced by the farmers was the lack of public procurement of the produce due to which farmers were left at the mercy of the private traders who procure their produce at prices lower than the recommended MSP followed by the exploitative practices by middlemen. The major problem identified by the cotton growers was the lack of remunerative price for their produce followed by fluctuation in price of the crop.

\section{REFERENCES}

Chahal, S.S. and Kataria, P. 2010. Constraints in the production and marketing of maize in Punjab. Agric. Update, 5(1\&2): 228-236.

Kshirsagar, K.G. 2006. Availing Marketing Infrastructure for Horticultural Crops: Emerging Perspectives and Future Policies. Ind. J. Agril. Mktg., 20(2): 69-80.

Kumari, M., Meena, L.K. and Singh, R.G. 2015. Problems and prospects of maize crop in eastern zone of Bihar. Int. J. of Agril. Sc., 5(2): 138-146.

Rajesh, R. and Sundaresan, R. 2002. Marketing Decision by Farmers and their Operational Constraints. Encycl. Agril. Mktg., 3: 269-82.

Ramkishen, Y. (ed) 2004. New Perspectives in Rural and Agricultural marketing. Jaico Publications, Mumbai, India.

Ramesh, S.V. 2014. Cotton cultivation and marketing- a study on prospects and problems in Tirupur district. Int. J. Ent. Innov. Mgmt. Studies, 1(3): 81-88. 